\title{
An Inventory of Crop Wild Relatives of the United States
}

\author{
Colin K. Khoury, ${ }^{\star}$ Stephanie Greene, John Wiersema, Nigel Maxted, Andy Jarvis, and Paul C. Struik
}

\section{ABSTRACT}

The use of crop wild relatives (CWRs) in breeding is likely to continue to intensify as utilization techniques improve and crop adaptation to climate change becomes more pressing. Significant gaps remain in the conservation of these genetic resources. As a first step toward a national strategy for the conservation of CWRs, we present an inventory of taxa occurring in the United States, with suggested prioritization of species based on potential value in crop improvement. We listed 4600 taxa from 985 genera and 194 plant families, including CWRs of potential value via breeding as well as wild species of direct use for food, forage, medicine, herb, ornamental, and/or environmental restoration purposes. United States CWRs are related to a broad range of important food, forage and feed, medicinal, ornamental, and industrial crops. Some potentially valuable species are threatened in the wild, including relatives of sunflower (Helianthus annuus L.), walnut (Juglans regia L.), pepo squash (Cucurbita pepo L.), wild rice (Zizania L.), raspberry (Rubus idaeus L.), and plum (Prunus salicina Lindl.), and few accessions of such taxa are currently conserved ex situ. We prioritize 821 taxa from 69 genera primarily related to major food crops, particularly the approximately 285 native taxa from 30 genera that are most closely related to such crops. Both the urgent collection for ex situ conservation and the management of such taxa in protected areas are warranted, necessitating partnerships between concerned organizations, aligned with regional and global initiatives to conserve and provide access to CWR diversity.
C.K. Khoury and A. Jarvis, International Center for Tropical Agriculture (CIAT), Km 17, Recta Cali-Palmira, Apartado Aéreo 6713, Cali, Colombia; C.K. Khoury and P.C. Struik, Centre for Crop Systems Analysis, Wageningen Univ., Droevendaalsesteeg 1, 6708 PB Wageningen, The Netherlands; S. Greene, United States Dep. of Agriculture, Agricultural Research Service, Plant Germplasm Introduction and Testing, 24106 North Bunn Rd., Prosser, WA 99350; J. Wiersema, United States Dep. of Agriculture, Agricultural Research Service, National Germplasm Research Laboratory, Building 003, BARC-West, Beltsville, MD 20705-2350; N. Maxted, School of Biosciences, Univ. of Birmingham, Edgbaston, Birmingham, B15 2TT, UK; A. Jarvis, CGIAR Research Program on Climate Change, Agriculture and Food Security (CCAFS), Km 17, Recta Cali-Palmira, Apartado Aéreo 6713, Cali, Colombia. Received 11 Oct. 2012. ^Corresponding author (c.khoury@cgiar.org).

Abbreviations: CWR, crop wild relative; FAOSTAT, Food and Agriculture Organization of the United Nations statistical database; GP, gene pool; GRIN, Germplasm Resources Information Network; ITPGR, International Treaty on Plant Genetic Resources for Food and Agriculture; NPGS, National Plant Germplasm System; TG, taxon group; USFS, U.S. Forest Service; WUS, wild utilized species.

$\mathrm{N}$ EARLY 40 yr ago Jack Harlan outlined the major factors explaining the extent of use of crop wild relatives (CWRs) in plant breeding. His list included the degree of domestication of the crop, the perceived genetic vulnerability of the crop, the availability of CWRs for use, the degree of difficulty in using CWRs in breeding, and the economic conditions and disposition of breeders toward their use (Harlan, 1976).

Use of CWRs has steadily increased over the past decades, providing improved pest and disease resistance, tolerance to abiotic

Published in Crop Sci. 53:1-13 (2013).

doi: $10.2135 /$ cropsci2012.10.0585

Freely available online through the author-supported open-access option. (C) Crop Science Society of America | 5585 Guilford Rd., Madison, WI 53711 USA

All rights reserved. No part of this periodical may be reproduced or transmitted in any form or by any means, electronic or mechanical, including photocopying, recording, or any information storage and retrieval system, without permission in writing from the publisher. Permission for printing and for reprinting the material contained herein has been obtained by the publisher. 
stresses, increased yield, novel cytoplasms, and quality traits to banana (Musa acuminata Colla), barley (Hordeum vulgare L.), bean (Phaseolus vulgaris L.), cassava (Manihot esculenta Crantz), chickpea (Cicer arietinum L.), corn (Zea mays L.), lettuce (Lactuca sativa L.), oat (Avena sativa L.), millet [Pennisetum glaucum (L.) R. Br.], potato (Solanum tuberosum L.), rice (Oryza sativa L.), sugarcane (Saccharum officinarum L.), sunflower, tomato (Solanum lycopersicum L.), and wheat (Triticum aestivum L.), among others (Gur and Zamir, 2004; Hajjar and Hodgkin, 2007; Iltis, 1988; Maxted et al., 2012a; McCouch et al., 2007; Xiao et al., 1996). Advancements in breeding, particularly through novel molecular approaches, have increased the efficiency of the use of wild germplasm substantially (Ford-Lloyd et al., 2011; Tanksley and McCouch, 1997; Volk and Richards, 2011; Zamir, 2001). Research for adaptation to future climates is likely to increase the exploitation of the variation represented in CWRs (Guarino and Lobell, 2011; Ortiz et al., 2008).

Despite substantial efforts over these years, the most significant bottleneck in use identified by Harlan-the availability of CWRs for research and breeding-continues to be of concern, with substantial genetic variation yet to be conserved and financial and political constraints still to be resolved (FAO, 2010; Fowler and Hodgkin, 2004).

An estimated one out of five plant species is threatened worldwide by habitat loss or modification, agricultural modernization, pollution, overexploitation, invasive species, and/or climate change (Brummitt and Bachman, 2010), and nearly $30 \%$ of the native flora of the United States is of conservation concern (CPC, 2012). Crop wild relatives are not exempt from these pressures (Bilz et al., 2011; Jarvis et al., 2008; Ureta et al., 2011; Wilkes, 2007).

The urgent collection and subsequent storage in ex situ facilities where these genetic resources can be made available for research and breeding is therefore warranted. The complementary protection of CWRs in situ is necessary to support the ongoing evolution of CWR populations (Heywood, 2008; Maxted and Kell, 2009; Maxted et al., 1997; Meilleur and Hodgkin, 2004), in both wild areas and traditional agricultural systems (GSPC, 2002; Rawal, 1975; Zizumbo-Villarreal et al., 2005).

It is becoming increasingly feasible to formulate comprehensive strategies for the conservation of CWR diversity due to advancements in understanding the taxonomic relationships between crops and their wild relatives (Andersson and de Vicente, 2010; Wiersema et al., 2012), improved availability of data on the distribution of these taxa (e.g., FNA, 2008a; GBIF, 2012), and increased power of distribution modeling and conservation analysis (Hijmans and Spooner, 2001; Jarvis et al., 2005; ParraQuijano et al., 2011; Ramírez-Villegas et al., 2010).

The starting point for CWR conservation planning typically involves the creation of a checklist of included CWR taxon names, to which ancillary data (e.g., ecogeographic information, conservation status, use potential, etc.) is added to generate an inventory for the target area of research (Maxted et al., 2008). National inventories of CWRs have been published for a growing list of nations, particularly in Europe (Magos Brehm et al., 2007; Maxted et al., 2012b), and targeted subsequent conservation efforts have been made in over 40 countries worldwide (Meilleur and Hodgkin, 2004). On the global level, a specialist group is active in listing CWRs of conservation concern (International Union for Conservation of Nature, Species Survival Commission, 2008), an initiative is underway to document, collect, conserve ex situ, and prebreed the CWRs of major food and forage crops (Guarino and Lobell, 2011), and progress is being made in planning for an integrated system of genetic reserves for the CWRs of highest priority worldwide (Maxted and Kell, 2009).

As a primary step in the process toward a national strategy for the conservation of CWRs, we report on an inventory of the CWR flora occurring in the United States and a prioritization of these taxa based on their potential value in agricultural crop research.

\section{The United States Context}

More than 20,000 species of plants, or about $7 \%$ of the world's flora, are native or naturalized in North America north of Mexico (FNA, 2008b), but the region has not been considered a major center of crop plant diversity (Vavilov, 1926). Those indigenous species that were domesticated before European contact in eastern North America include pepo squash, sunflower, marsh-elder (Iva annua L.), and chenopod (Chenopodium berlandieri Moq.) (Smith, 2006) and in the arid southwestern United States include Sonoran panic (Panicum hirticaule J. Presl var. hirticaule) (Nabhan, 1985) and devil's-claw [Proboscidea parviflora (Wooton) Wooton and Standl. subsp. parviflora] (Bretting and Nabhan, 1986). Blueberry (Vaccinium section Cyanococcus) and cranberry (Vaccinium section Oxycoccus) (Ballington, 2001), blackberry (Rubus fruticosus L., sensu lato and hybrids) (Finn, 2001), and pecan [Carya illinoinensis (Wangenh.) K. Koch] (Flack, 1970) may be counted as more recent domestications. The number of CWRs native to the United States may therefore at first glance be estimated to be fairly small.

Three factors significantly increase the number of potentially valuable CWRs. The relatives of a complex of Mesoamerican crop species, including corn, a number of bean (Phaseolus L.) and squash species, chili pepper (Capsicum L.), American cotton (Gossypium hirsutum L.), and tobacco (Nicotiana rustica L.) (Nabhan, 1985; ZizumboVillarreal and Colunga-GarcíaMarín, 2010), are distributed in the southern regions of the United States (USDA-ARS National Genetic Resources Program, 2012). Second, a number of crops domesticated in other temperate regions of the world are congeneric with species occurring in the United States, for example, strawberry (Fragaria L.) 
(Hummer et al., 2011) and hops (Humulus L.) (Peredo et al., 2010). Finally, approximately 4000 plant species have been introduced to the region since the Colombian Exchange (Guo et al., 2009), including weedy relatives of crop plants.

Several well-documented examples of use of native CWRs in breeding exist. North American wild grape (Vitis L.) germplasm proved critical in providing resistance to phylloxera (Phylloxera vitifoliae Fitch) as a rootstock in European grape (Vitis vinifera L.) production in the late 1800s, and these stocks continue to provide the basis for protection worldwide (Gale, 2003). Genes for resistance to a range of diseases and pests, including rust (Puccinia helianthi Schwein.), downy mildew [Plasmopara halstedii (Farl.) Berl. \& De Toni], powdery mildew [Golovinomyces cichoracearum (DC.) V.P. Heluta], broomrape (Orobanche cumana Wallr.), sclerotinia head and stalk rot [Sclerotinia sclerotiorum (Lib.) de Bary], and sunflower moth (Homoeosoma electellum Hulst), have been identified in native sunflowers and successfully transferred into cultivars (Seiler and Gulya, 2004).

SeveralU.S. government entities supportactivities focused on CWR conservation. The USDA-ARS National Plant Germplasm System (NPGS) published in situ conservation guidelines for U.S. CWRs (Plant Germplasm Operations Committee, 1999) and recently formed a subcommittee on CWRs within the Plant Germplasm Operations Committee (Plant Germplasm Operations Committee, 2010). The NPGS Germplasm Resources Information Network (GRIN) Taxonomy Section is preparing a database of crop gene pools listing CWRs based on an evaluation of breeding and crossability studies (Wiersema et al., 2012).

Over the past decade the NPGS has supported 61 explorations for the U.S. CWRs of food, forage, woody landscape, and ornamental crop plants (K. Williams, personal communication, 2012). Genetic reserves for the wild relatives of grape (Pavek et al., 2001), chili pepper (Nabhan, 1990), and cranberry (K. Hummer, personal communication, 2010) have been established. Explorations regarding possible locations and feasibility of protected areas for CWRs of pecan, potato, sweet pea (Lathyrus L.), and edible alliums (Allium L.) were also completed (Plant Germplasm Operations Committee, 1999).

The U.S. Forest Service (USFS) actively maintains a number of CWR populations in National Forests (USFS, 2010) and CWRs are informally conserved across the United States on these and other public lands. The Bureau of Land Management, in partnership with the Millennium Seed Bank of the Royal Botanic Gardens, Kew, and local organizations across the country, has collected CWR accessions within the "Seeds of Success" Program (Bureau of Land Management, 2012). Building on a partnership between ARS and USFS to collaborate on the establishment of in situ reserves for U.S. CWRs, the agencies are in the process of developing a coordinated strategy for CWR management (L. Stritch, personal communication, 2012).

\section{MATERIALS AND METHODS}

\section{National Inventory of Crop Wild Relatives}

To broadly cover the wild plant species occurring in the United States that have potential value in crop research, we compiled an inventory of CWRs that may be used in crop breeding as well as wild utilized species (WUS) directly used for food, forage, medicine, herb, ornamental, and/or environmental restoration purposes. Very few WUS are the central focus of plant breeding programs although some taxa may be semidomesticated, and WUS may have a high potential for crop development.

For listed CWRs we aimed to include the full range of taxa with the potential to contribute to crop improvement, including both those species where gene exchange with the crop is relatively straightforward and more distant relatives requiring advanced techniques to produce viable hybrid progeny. Our starting point for defining CWRs followed Maxted et al. (2006, p. 2680): "A crop wild relative is a wild plant taxon that has an indirect use derived from its relatively close genetic relationship to a crop; this relationship is defined in terms of the CWR belonging to Gene Pools (GPs) 1 or 2, or taxon groups (TGs) 1 to 4 of the crop." The definition classifies taxa based on whether they occur in Harlan and de Wet's (1971) crop GPs 1 or 2, encompassing closely related taxa that are relatively easy to cross using conventional methods in breeding programs. If data from interspecific hybridization or genetic relatedness studies are unavailable, Maxted et al. (2006) proposed a classification system based on taxonomic groups equating to rank in relation to the crop species. Data on gene pool and taxon group concepts for available crops was gathered from GRIN taxonomy (Wiersema et al., 2012) and from the "Harlan and de Wet Crop Wild Relative Inventory” (Vincent et al., 2012).

A growing number of crops have benefited from traits introgressed from distant gene pools (Abberton, 2007; Ballington, 2001; Bradshaw et al., 2006; Chuda and Adamus, 2009; Frese et al., 2001; Mallikarjuna et al., 2006; Mii, 2009; Rygulla et al., 2007), and as breeding techniques improve, taxa from such gene pools are increasingly likely to be of interest to crop improvement programs. Such species are additionally useful for taxonomic and evolutionary research. We therefore broadened our CWR definition to include species in the tertiary gene pool. In some crops these may include taxa from related genera (e.g., Tripsacum L. for maize, Aegilops L. and Amblyopyrum Eig for wheat [Wiersema et al., 2012]).

Crop wild relatives and WUS taxa occurring in the United States were compiled from the GRIN World Economic Plants database (USDA-ARS National Genetic Resources Program, 2011), based on Wiersema and León (1999), completed volumes of the Flora of North America (FNA, 2008a), McGuffin (2000), and the Native Seed Network Database (Native Seed Network, 2010). Both native and introduced taxa were included. In addition to listing taxa to the infraspecific level, information on origin status, number of accessions (available plus unavailable) in GRIN, noxious weed status, associated crop, crop gene pool, and associated crop use was obtained. Taxa with multiple uses were listed first by their primary use and thereafter by subsequent uses. For taxa with uses both as CWRs and WUS, use as a genetic resource was prioritized over direct uses. Additional data on occurrence and weed status was gathered from the 
PLANTS Database (USDA-NRCS, 2010). The threat status of taxa was recorded from NatureServe (NatureServe, 2009) and the International Union for Conservation of Nature Red List of Threatened Species (IUCN, 2012).

Taxonomic verification was performed via the "Taxonomic Name Resolution Service" (Boyle et al., 2013) and GRIN taxonomy (USDA-ARS National Genetic Resources Program, 2012), the latter of which served as the final authority. The Inventory was reviewed by NPGS curators, members of the NPGS Crop Germplasm Committees, and USDA-ARS crop experts, who submitted revisions and proposed additional taxa.

\section{Prioritization of the Crop Wild Relatives of Agricultural Crops}

When using an inclusive definition for crops together with a broad definition of CWRs, national and regional studies have resulted in the majority of flora being listed as CWRs. Approximately $80 \%$ of the species in the European and Mediterranean floras were listed as CWRs in an inventory for that region (Kell et al., 2008), and 77\% of the flora of Portugal similarly listed as CWRs or WUS (Magos Brehm et al., 2007). Given the extent of potentially useful plant taxa in the United States and general resource constraints in conservation and research funding, we further prioritized taxa within the Inventory to focus subsequent conservation efforts on species with the greatest potential impact on crop research.

We first compiled and prioritized crop species based on their contribution to global agricultural production and food security, with the assumption that important crops are the focus of the most active breeding programs with experience in the use of exotic germplasm. The crop list was collated from the Food and Agriculture Organization of the United Nations statistical database (FAOSTAT) production and food supply data (FAO, 2011), Annex 1 of the International Treaty on Plant Genetic Resources for Food and Agriculture (ITPGR) (FAO, 2002), Appendix 2 ("Important Food Crops") of Groombridge and Jenkins (2002), and PrescottAllen and Prescott-Allen (1990). These sources emphasize food crops but some include fiber, forage, and industrial crops.

Listed crops were further prioritized based on the number of sources and importance attributed within the sources: (i) major crops (Priority 1) were assigned to crops listed in more than one source, among the specific crop commodities listed in FAOSTAT and in Prescott-Allen and Prescott-Allen (1990), and all crops in Annex 1 of the ITPGR and in Groombridge and Jenkins (2002) and (ii) minor and nonfood crops (Priority 2) were assigned to crops listed in only one source, plus crops recorded in FAOSTAT general commodities as well as Annex 1 forages and the "Brassica complex" crops other than those in the genus Brassica L. itself. The resulting compilation of the world's major crops included 242 crops and 268 genera (101 crops and 119 genera in Priority 1 and 141 crops and 149 genera in Priority 2) (Supplemental Table S1). The list included all agricultural crops recorded in FAOSTAT as important to production or to food supply in the United States (FAO, 2011).

The National Inventory was compared to the world's major crops list and crosschecked with GRIN taxonomy to derive a list of CWR taxa occurring in the United States that are within the gene pools of priority crops. The resulting list of priority CWRs was reviewed by NPGS curators, members of the NPGS Crop Germplasm Committees, and ARS crop experts.
Priority 1 CWR taxa were further categorized based on perceived value and ease of use in breeding programs. Native plant species were assigned a higher priority, as they have a long history of adaptation in contrast to naturalized species, which may have limited variation due to the founder effect (Amsellem et al., 2001). Closely related (defined here as within GPs 1-2 or TGs 1-3) native taxa, plus any additional taxa recorded in the literature or identified by researchers as potentially useful in crop breeding, were assigned the highest priority (Priority 1A). Distantly related and/or nonnative taxa that were not specifically identified by the research community as a target for use were listed as Priority 1B. The few gene pools (notably blackberry and raspberry in Rubus L.) for which relatedness information was not available were categorized based on occurrence status.

\section{RESULTS AND DISCUSSION}

The National Inventory contains 4596 taxa, representing 3912 species from 985 genera and 194 plant families. Crop wild relatives in the inventory are represented by 2495 taxa representing 1905 species from 160 genera and 56 families. Wild utilized species are represented by 2101 taxa from 2007 species from 833 genera and 182 families. Major families are listed in Table 1. The Inventory is available online at http://www.ars-grin.gov/misc/tax/ (accessed 1 Oct. 2012). Future plans are to fully integrate these data into GRIN so that detailed information is available for each taxon and the Inventory can be queried by taxonomy, priority level, and geographic distribution.

Crop wild relatives identified in the United States are primarily related to food crops (Table 2). These include genetic resources for globally important crops such as strawberry, sunflower, sweet potato [Ipomoea batatas (L.) Lam.], bean, stone fruits (Prunus L.), and grape as well as regionally important crops such as pecan, yerba maté (Ilex paraguariensis A. St.-Hil.), quinoa (Chenopodium quinoa Willd.), and cranberry. Forage and feed CWRs are also well represented, particularly legumes (Trifolium L., Lupinus L., Lotus L., and Astragalus L.) and grasses (Agrostis L., Bromus L., Festuca L., and Poa L.). Significant genetic resources of medicinal crops include Echinacea (Echinacea Moench), tobacco (Nicotiana L.), St. John's-wort (Hypericum L.), poppy (Papaver L.), and artemisia (Artemisia L). Crop wild relatives of ornamental crops include Rosa L., Coreopsis L., Lilium L., Phlox L., Rudbeckia L., and Penstemon Schmidel. Crop wild relatives of material and industrial crops include relatives of flax (Linum L.), cotton (Gossypium L.), and jatropha (Jatropha L).

The WUS species listed as distributed in the United States are primarily used for ornamental, restoration, and medicinal purposes. A number of food species of cultural and economic significance are also identified, such as wild rice, sugar maple (Acer saccharum Marshall), and pawpaw [Asimina triloba (L.) Dunal].

Nonnative species make up $12.3 \%$ of the Inventory (14.7\% of CWRs and 9.6\% of WUS), and 212 taxa (4.6\% of total) are federal and/or state listed noxious weeds. 
Genetic resource priorities for listed taxa should take into account weed regulations and conservation priorities for the species affected by these invasive plants.

Several introduced CWR taxa were identified as containing genetic resources of interest to breeders, including relatives of beet (Beta vulgaris L.) (L. Panella, personal communication, 2011), lettuce (B. Hellier, personal communication, 2011), and clover (W. Williams, personal communication, 1997). Recent alfalfa (Medicago sativa L.) breeding efforts have used cold-adapted naturalized populations of Medicago sativa L. subsp. falcata (L.) Arcang. from South Dakota to develop rangeland varieties adapted to the Intermountain West (Peel et al., 2009). These examples demonstrate the potential value of novel variation in naturalized species (Bossdorf et al., 2005), which should not be neglected in inventories of useful plant species.

The threat status of $3512(76.4 \%)$ taxa in the Inventory has been recorded in NatureServe. Eight $(0.2 \%)$ taxa were assessed as known or presumed extinct in the wild, 115 (2.5\%) as globally critically imperiled and 111 (2.4\%) as imperiled, 337 (7.3\%) vulnerable, 798 (17.4\%) apparently secure, and 2143 (46.6\%) globally secure. Of the included taxa, the International Union for Conservation of Nature Red List of Threatened Species assessed 16 taxa as extinct, endangered, or vulnerable (IUCN, 2012). Sixty-two taxa are listed as endangered under the U.S. Endangered Species Act (Endangered Species Act of 1973, 16 U.S.C. Sec 1531), 10 taxa as threatened, and 11 taxa as candidates for listing (NatureServe, 2009). Among the taxonomic groups with the largest number of threatened taxa are members of the family Fabaceae, particularly within
Table 1. Major families of U.S. crop wild relatives (CWRs) and wild utilized species (WUS).

\begin{tabular}{|c|c|c|c|c|c|}
\hline \multicolumn{3}{|c|}{ CWRs } & \multicolumn{3}{|c|}{ WUS } \\
\hline Families & $\begin{array}{l}\text { No. of } \\
\text { genera }\end{array}$ & $\begin{array}{c}\text { No. of } \\
\text { taxa }\end{array}$ & Families & $\begin{array}{c}\text { No. of } \\
\text { genera }\end{array}$ & $\begin{array}{c}\text { No. of } \\
\text { taxa }\end{array}$ \\
\hline Fabaceae & 19 & 693 & Asteraceae & 97 & 216 \\
\hline Poaceae & 31 & 448 & Poaceae & 71 & 156 \\
\hline Asteraceae & 12 & 182 & Rosaceae & 29 & 135 \\
\hline Rosaceae & 6 & 163 & Fabaceae & 52 & 106 \\
\hline Amaranthaceae & 6 & 137 & Ericaceae & 23 & 79 \\
\hline Brassicaceae & 11 & 67 & Pinaceae & 6 & 71 \\
\hline Grossulariaceae & 1 & 67 & Cyperaceae & 6 & 55 \\
\hline Solanaceae & 4 & 63 & Salicaceae & 2 & 48 \\
\hline Cyperaceae & 1 & 48 & Ranunculaceae & 14 & 45 \\
\hline Amaryllidaceae & 1 & 47 & Boraginaceae & 17 & 43 \\
\hline Other (46) & 68 & 580 & Other (172) & 516 & 1147 \\
\hline
\end{tabular}

the genera Astragalus, Lotus, Lupinus, and Trifolium (see Supplemental Table S2 for a full listing of extinct, imperiled, endangered, and threatened taxa).

Threatened species with known or high potential value in crop breeding include the wild walnut Juglans hindsii (Jeps.) R. E. Sm., which is used as a primary rootstock for English walnut worldwide and is critically imperiled in its native California habitat (Phillips and Meilleur, 1998), and close relatives of sunflower, squash, cotton, gooseberry (Ribes uva-crispa L.), raspberry, onion (Allium cepa L.), wild rice, and plum (Table 3). The conservation of these genetic resources should be prioritized urgently.

Over 96,000 gene bank accessions of 2800 taxa listed in the Inventory are recorded in GRIN, but a large proportion

Table 2. Uses of U.S. crop wild relatives (CWRs) and wild utilized species (WUS).

\begin{tabular}{|c|c|c|c|c|}
\hline Use & Major families (and number of taxa) & $\begin{array}{l}\text { No. of } \\
\text { families }\end{array}$ & $\begin{array}{l}\text { No. of } \\
\text { genera }\end{array}$ & $\begin{array}{l}\text { No. of } \\
\text { taxa }\end{array}$ \\
\hline \multicolumn{5}{|c|}{ CWRs (genetic resource of) } \\
\hline Food & $\begin{array}{l}\text { Poaceae (304), Fabaceae (168), Rosaceae (136), Amaranthaceae (95), Asteraceae } \\
\text { (90), Grossulariaceae (67), Brassicaceae (61), Solanaceae (54), Cyperaceae (48), } \\
\text { Amaryllidaceae (47), Convolvulaceae (40), Ericaceae (39), and Asparagaceae (35) }\end{array}$ & 47 & 103 & 1472 \\
\hline Forage and feed & Fabaceae (521), Poaceae (142), and Amaranthaceae (42) & 5 & 29 & 709 \\
\hline Medicinal & Asteraceae (63), Hypericaceae (44), and Euphorbiaceae (17) & 7 & 10 & 150 \\
\hline Ornamental & Plantaginaceae (39), Rosaceae (27), and Asteraceae (19) & 5 & 6 & 99 \\
\hline Material and industrial & Linaceae (21), Malvaceae (13), and Asteraceae (8) & 10 & 15 & 57 \\
\hline Herb & Lamiaceae (5) & 1 & 2 & 5 \\
\hline Soil conservation & Fabaceae (3) & 1 & 1 & 3 \\
\hline \multicolumn{5}{|c|}{ WUS (direct use for) } \\
\hline Ornamental & $\begin{array}{l}\text { Ericaceae (65), Asteraceae (49), Fabaceae (43), Rosaceae (41), Salicaceae (30), } \\
\text { Oleaceae (22), Poaceae (20), Papaveraceae (17), and Ranunculaceae (16) }\end{array}$ & 149 & 440 & 812 \\
\hline Restoration & $\begin{array}{l}\text { Asteraceae (151), Poaceae (53), Cyperaceae (48), Fabaceae (31), Boraginaceae (29), } \\
\text { Ranunculaceae (26), Rhamnaceae (26), Apiaceae (23), Onagraceae (22), Liliaceae } \\
\text { (22), Polygonaceae (18), and Rosaceae (17) }\end{array}$ & 83 & 336 & 755 \\
\hline Medicinal & Asteraceae (12), Lamiaceae (11), and Fabaceae (9) & 82 & 139 & 180 \\
\hline Food & Rosaceae (72), Poaceae (6), and Sapindaceae (5) & 17 & 26 & 112 \\
\hline Forage and feed & Poaceae (72), Fabaceae (11), and Araceae (5) & 9 & 61 & 99 \\
\hline Forestry & Pinaceae (49), Cupressaceae (7), and Betulaceae (7) & 16 & 28 & 87 \\
\hline Material and industrial & Fagaceae (9) and Cupressaceae (6) & 26 & 37 & 52 \\
\hline Soil conservation & Fabaceae (3) & 1 & 3 & 3 \\
\hline Turf & Poaceae (1) & 1 & 1 & 1 \\
\hline
\end{tabular}


Table 3. Threatened U.S. crop wild relatives of major crops.

\begin{tabular}{|c|c|c|c|c|}
\hline Taxon & $\begin{array}{c}\text { Priority } \\
\text { category }\end{array}$ & U.S. ESA ${ }^{\ddagger}$ & NatureServe ${ }^{\ddagger}$ & $\begin{array}{c}\text { No. of } \\
\text { accessions }^{\S}\end{array}$ \\
\hline Allium munzii (Ownbey \& Aase ex Traub) McNeal & P1B & LE & G1 & 0 \\
\hline Allium obtusum Lemmon var. conspicuum Mortola \& McNeal & $\mathrm{P} 1 \mathrm{~B}$ & & T2 to 3 & 0 \\
\hline Allium scilloides Douglas ex S. Watson & P1B & & G2 to 3 & 0 \\
\hline Cucurbita okeechobeensis (Small) L. H. Bailey & P1A & LE & G1 & 0 \\
\hline Fragaria chiloensis (L.) Mill. subsp. sandwicensis (Decne.) Staudt & P1A & & $\mathrm{T} 2$ & 2 \\
\hline Gossypium tomentosum Nutt. ex Seem. & P1A & & G2 to 3 & 0 \\
\hline Helianthus carnosus Small & P1B & & G1 to 2 & 2 \\
\hline Helianthus niveus (Benth.) Brandegee subsp. tephrodes (A. Gray) Heiser & P1A & & G2ף & 10 \\
\hline Helianthus nuttallii Torr. \& A. Gray subsp. parishii (A. Gray) Heiser & $\mathrm{P} 1 \mathrm{~B}$ & & GXף & 0 \\
\hline Helianthus paradoxus Heiser & P1A & & G2 & 1 \\
\hline Helianthus smithii Heiser & P1B & & G2 & 6 \\
\hline Helianthus verticillatus Small & P1B & & G1 & 2 \\
\hline Hordeum arizonicum Covas & $\mathrm{P} 1 \mathrm{~B}$ & & G2 to 4 & 0 \\
\hline Ipomoea microdactyla Griseb. & P1B & & G2 & 1 \\
\hline Juglans hindsii (Jeps.) R. E. Sm. & P1A & & G1 & 16 \\
\hline Lathyrus grimesii Barneby & P1B & & G2 & 3 \\
\hline Lathyrus holochlorus (Piper) C. L. Hitchc. & P1B & & G2 & 1 \\
\hline Leymus pacificus (Gould) D. R. Dewey & P1B & & G2 to 3 & 0 \\
\hline Manihot walkerae Croizat & $\mathrm{P} 1 \mathrm{~B}$ & LE & G1 & 0 \\
\hline Phaseolus texensis A. Delgado \& W. R. Carr & $\mathrm{P} 1 \mathrm{~B}$ & & G2 & 0 \\
\hline Prunus eremophila Prigge & P1B & & G1 & 0 \\
\hline Prunus murrayana E. J. Palmer & P1A & & $\mathrm{GX}$ & 0 \\
\hline Ribes binominatum A. Heller & P1A & & G2 to 3 & 3 \\
\hline Ribes echinellum (Coville) Rehder & P1B & LT & G1 & 3 \\
\hline Ribes erythrocarpum Coville \& Leiberg & P1B & & G2 & 2 \\
\hline Rubus aliceae L. H. Bailey & P1A & & GX & 0 \\
\hline Rubus hawaiensis A. Gray & P1A & & G2 to 3 & 13 \\
\hline Rubus macraei A. Gray & P1A & & G2 & 1 \\
\hline Solanum incompletum Dunal & P1B & LE & G1 & 0 \\
\hline Solanum nelsonii Dunal & P1B & C & G2 & 0 \\
\hline Solanum sandwicense Hook. \& Arn. & P1B & LE & G1 & 0 \\
\hline Solanum wallacei (A. Gray) Parish & P1B & & G2 & 0 \\
\hline Tripsacum floridanum Porter ex Vasey & P1A & & G2 & 0 \\
\hline Vanilla mexicana Mill. & P1A & & G2 to 4 & 0 \\
\hline Vicia menziesii Spreng. & P1B & LE & G1 & 0 \\
\hline Vicia ocalensis R. K. Godfrey \& Kral & P1B & & G1 & 1 \\
\hline Zizania texana Hitchc. & P1A & LE & G1 & 0 \\
\hline
\end{tabular}

${ }^{\dagger}$ P1A, native taxa closely related to important crop plants; P1B, nonnative and/or distantly related to important crop plants.

FTaxa listed as endangered (LE), threatened (LT), or as a candidate for listing (C) under the U.S. Endangered Species Act (Endangered Species Act of 1973, 16 U.S.C. Sec 1531) (U.S. ESA), and/or listed as known or presumed extinct in the wild (GX), globally critically imperiled (G1), and globally imperiled (G2) in NatureServe (NatureServe, 2009). Note: G3 is categorized as globally vulnerable and G4 as apparently secure and T denotes global listing at the infraspecific level.

§Number of accessions denotes National Plant Germplasm System germplasm listed as wild and collected in the United States.

"Threat assessment at the species level.

of this material is cultivated germplasm conspecific with wild taxa such as American cotton (G. hirsutum) and chili pepper (Capsicum annuum L.). Germplasm of Inventory taxa listed as wild total 48,780 accessions, and that listed as both wild and from the United States total 20,739 accessions from 2135 taxa. These accessions are distributed unevenly within the Inventory, with 51.8\% of accessions comprising 14 genera (Fraxinus L., Helianthus L., Pinus L., Avena L., Elymus L., Vacinium L., Rubus L., Vitis L., Fragaria L., Lupinus L., Achnatherum P. Beauv., Ribes L., Solanum L., and Trifolium L.). Of the 232 taxa listed as endangered, threatened, or as a candidate for listing under the
Endangered Species Act (Endangered Species Act of 1973, 16 U.S.C. Sec 1531) as well as taxa listed as known or presumed extinct in the wild, globally critically imperiled, and imperiled in NatureServe (2009), only 157 accessions listed as wild and collected in the United States are conserved in the NPGS.

\section{Priority Crop Wild Relatives of Agricultural Crops}

Priority species occurring in the United States total 2256 taxa within 176 genera. These include 821 taxa from 69 genera related to 63 major agricultural crops (Priority 1 
Table 4. Priority U.S. crop wild relatives and wild utilized species.

\begin{tabular}{|c|c|c|c|c|c|}
\hline Genus & Associated crop name & $\begin{array}{c}\text { Priority } \\
(\text { and } \text { no. of taxa })^{\dagger}\end{array}$ & Genus & Associated crop name & $\begin{array}{c}\text { Priority } \\
\text { (and no. of taxa) }\end{array}$ \\
\hline Acer & Sugar maple & P1A (6) & Juglans & Walnut & P1A (7) and P1B (2) \\
\hline Aegilops & Wheat & P1B (5) & Lactuca & Lettuce & P1A (10) and P1B (1) \\
\hline Agropyron & Wheat & P1B (2) & Lathyrus & Grasspea & P1B (31) \\
\hline Allium & Onion, garlic, and leek & P1A (4) and P1B (43) & Leymus & Wheat & P1B (17) \\
\hline Artocarpus & Breadfruit and jackfruit & P1B (1) & Malus & Apple & P1B (4) \\
\hline Asparagus & Asparagus & P1B (3) & Manihot & Cassava & P1B (4) \\
\hline Avena & Oat & P1B (3) & Medicago & Alfalfa & P1B (10) \\
\hline Beta & Beet, sugar beet, and chard & P1A (4) & Nicotiana & Tobacco & P1B (9) \\
\hline Brassica & Cabbage, rapeseed, etc. & P1B (5) & Olea & Olive & P1B (1) \\
\hline Capsicum & Chili pepper and sweet pepper & P1A (2) & Pennisetum & Pearl millet & P1B (10) \\
\hline Carica & Papaya & P1B (1) & Persea & Avocado & P1B (3) \\
\hline Carthamus & Safflower & P1B (1) & Phaseolus & Bean & P1A (4) and P1B (15) \\
\hline Carya & Pecan & P1A (9) and P1B (4) & Piper & Pepper & P1B (1) \\
\hline Castanea & Chestnut & P1A (3) and P1B (2) & Pistacia & Pistachio & P1A (1) \\
\hline Cinnamomum & Cinnamon & P1B (1) & Prunus & Stone fruits & P1A (17) and P1B (26) \\
\hline Cocos & Coconut & P1B (1) & Psathyrostachys & Wheat & P1B (2) \\
\hline Colocasia & Taro & P1B (1) & Pseudoroegneria & Wheat & P1B (1) \\
\hline Corylus & Hazelnut & P1A (3) & Psidium & Guava & P1A (1) and P1B (1) \\
\hline Cucumis & Melon & P1B (4) & Pyrus & Pear & P1B (1) \\
\hline Cucurbita & Pumpkin and squash & P1A (8) and P1B (2) & Ribes & Currant and gooseberry & $\mathrm{P} 1 \mathrm{~A}(27)$ and P1B (40) \\
\hline Cynara & Artichoke & P1B (3) & Rubus & Raspberry and blackberry & P1A (58) and P1B (10) \\
\hline Daucus & Carrot & P1B (2) & Saccharum & Sugar cane & P1B (9) \\
\hline Dioscorea & Yam & P1B (3) & Solanum & Potato and tomato & P1A (1) and P1B (38) \\
\hline Diospyros & Persimmon & P1A (2) & Sorghum & Sorghum & P1B (4) \\
\hline Diplotaxis & Cabbage, rapeseed, etc. & P1B (2) & Syzygium & Clove & P1B (2) \\
\hline Elymus & Wheat & P1B (43) & Thinopyrum & Wheat & P1B (2) \\
\hline Ficus & Fig & P1A (1) and P1B (3) & Tripsacum & Maize & P1A (4) \\
\hline Foeniculum & Fennel & P1B (1) & Vaccinium & Blueberry and cranberry & P1A (23) and P1B (16) \\
\hline Fragaria & Strawberry & P1A (11) and P1B (10) & Vanilla & Vanilla & P1A (2) \\
\hline Gossypium & Cotton & P1A (3) & Vernicia & Tung nut & P1B (1) \\
\hline Helianthus & Sunflower & P1A (23) and P1B (49) & Vicia & Fava bean and vetch & P1B (14) \\
\hline Hordeum & Barley & P1B (18) & Vigna & Cowpea, bambara groundnut, etc. & P1B (2) \\
\hline Ilex & Maté & P1A (6) and P1B (15) & Vitis & Grape & P1A (29) \\
\hline Illicium & Star-anise & P1A (1) & Zizania & Wild rice & $\mathrm{P} 1 \mathrm{~A}(6)$ \\
\hline Ipomoea & Sweet potato & P1A (9) and P1B (31) & & & \\
\hline
\end{tabular}

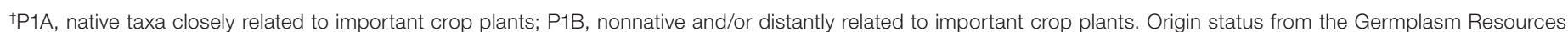

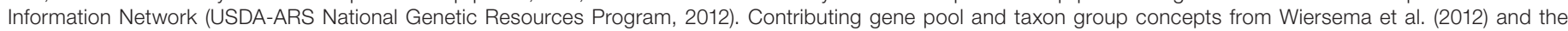
"Harlan and de Wet Crop Wild Relative Inventory" (Vincent et al., 2012).

gene pools) (Table 4) and 1435 taxa from 107 genera of minor food crops, forages, and other crops (Priority 2) (Supplemental Table S3). Within Priority 1, 285 closely related, native taxa from 30 genera are listed $1 \mathrm{~A}$ and 536 distantly related and/or nonnative taxa within 57 genera in $1 \mathrm{~B}$.

A number of iconic U.S. edible WUS were given priority for conservation considerations. Within Priority 1, these include sugar maple, wild rice, and American chestnut [Castanea dentata (Marshall) Borkh.], plants that have held important stature in traditional regional diets. In addition, 148 food, medicinal, and ornamental WUS from 22 genera were assigned to Priority 2.

At least 17 major crops have benefited from traits contributed by 55 Priority 1 CWR taxa (Table 5). As this count is limited to published references, it is likely an underestimate of the taxa occurring in the United States that have been successfully used in breeding programs.

The NPGS conserves 8195 accessions of wild native Priority 1 taxa (3952 Priority 1A and 4243 Priority 1B) and 4020 accessions of Priority 2 taxa. Of Priority 1 CWRs, $366(44.6 \%)$ taxa are completely absent from ex situ collections and another 307 (37.4\%) are represented by less than 10 germplasm accessions.

Far from possessing few genetic resources, the United States contains a wealth of native and introduced plants related to a broad range of crops. Significant gaps in the ex situ collections of these taxa remain to be filled, and a number of potentially valuable species are threatened in the wild. Meanwhile, new populations of some species are still being discovered (Kraft et al., 2012). Crops that are nationally as well as globally important to food 
Table 5. Confirmed use of priority crop wild relatives.

\begin{tabular}{|c|c|}
\hline Taxon & Trait $^{\dagger}$ \\
\hline Aegilops cylindrica Host & Salt tolerance (Farooq et al., 1995; Wang et al., 2003) \\
\hline Aegilops geniculata Roth & Hessian fly resistance (El Khlifi et al., 2004) \\
\hline Aegilops tauschii Coss. & $\begin{array}{l}\text { Rust resistance (Cox et al., 1995), wheat soil-borne mosaic virus, wheat spindle-streak mosaic virus (Cox } \\
\text { et al., 1995), drought tolerance (Gororo et al., 2002), yellow rust and leaf rust resistance (Ma et al., 1995), } \\
\text { glutenins improvement (Pena et al., 1995), agronomic traits, yield improvement (Pestsova et al., 2006), hessian } \\
\text { fly resistance (Suszkiw, 2005), karnal bunt (Villareal et al., 1996), water-logging tolerance (Villareal et al., 2001), } \\
\text { and sprouting suppression (Xiu-Jin et al., 1997). }\end{array}$ \\
\hline Allium fistulosum L. & Disease resistance (Khrustaleva and Kik, 1998) \\
\hline Avena sterilis L. & Crown rust resistance (Hoffman et al., 2006) and yield improvement (Takeda and Frey, 1976) \\
\hline Corylus americana Marshall & Eastern filbert blight resistance (Thompson et al., 1996) \\
\hline Helianthus anomalus S. F. Blake & Fertility restoration (Seiler, 1991a) \\
\hline Helianthus argophyllus Torr. \& A. Gray & $\begin{array}{l}\text { Downy mildew resistance (Hulke et al., 2010; Miller and Gulya, 1988), disease resistance (Jan et al., 2004), and } \\
\text { fertility restoration (Seiler, 1991a) }\end{array}$ \\
\hline Helianthus bolanderi A. Gray & Genetic stock (Jan, 1992) and fertility restoration (Seiler, 1991a) \\
\hline Helianthus debilis Nutt. & Powdery mildew resistance (Jan and Chandler, 1988) and fertility restoration (Seiler, 1991a) \\
\hline Helianthus deserticola Heiser & Downy mildew resistance (Seiler, 1991b) \\
\hline Helianthus divaricatus L. & Broomrape resistance (Jan et al., 2002) \\
\hline Helianthus giganteus L. & Fertility restoration (Seiler, 2000) and cytoplasmic male sterility (Whelan and Dedio, 1980) \\
\hline Helianthus grosseserratus M. Martens & Broomrape resistance (Jan et al., 2002) \\
\hline Helianthus hirsutus Raf. & Fertility restoration (Seiler, 1991c, 2000) \\
\hline Helianthus maximiliani Schrad. & Broomrape resistance (Jan et al., 2002) and cytoplasmic male sterility (Whelan and Dedio, 1980) \\
\hline Helianthus neglectus Heiser & Fertility restoration (Seiler, 1991a) \\
\hline Helianthus paradoxus Heiser & Salt tolerance (Lexer et al., 2004) and fertility restoration (Seiler, 1991a) \\
\hline Helianthus pauciflorus Nutt. & Cytoplasmic male sterility (Jan et al., 2006) and sclerotinia resistance (Miller and Gulya, 1999) \\
\hline Helianthus petiolaris Nutt. & $\begin{array}{l}\text { Verticillium resistance (Hoes et al., 1973), disease resistance (Jan et al., 2004), cytoplasmic male sterility } \\
\text { (Prescott-Allen and Prescott-Allen, 1986), sunflower moth resistance (Rogers et al., 1984), and fertility } \\
\text { restoration (Seiler, 1991a) }\end{array}$ \\
\hline Helianthus praecox Engelm. \& A. Gray & $\begin{array}{l}\text { Downy mildew, rust, verticillium wilt and broomrape resistance (Hajjar and Hodgkin, 2007), fertility restoration } \\
\text { (Seiler, 1991a), and downy mildew resistance (Seiler, 1991b) }\end{array}$ \\
\hline Helianthus resinosus Small & Fertility restoration (Seiler, 1991c) \\
\hline Helianthus strumosus L. & Fertility restoration (Seiler, 2000) \\
\hline Helianthus tuberosus L. & $\begin{array}{l}\text { Broomrape resistance (Putt, 1978), sunflower moth resistance (Rogers et al., 1984), and fertility restoration } \\
\text { (Seiler, 2000) }\end{array}$ \\
\hline Hordeum bulbosum L. & $\begin{array}{l}\text { Powdery mildew resistance (Pickering and Johnston, 2005), mosaic virus resistance (Ruge-Wehling et al., } \\
\text { 2006), septoria resistance (Toubia-Rahme et al., 2003), and leaf rust resistance (Zhang et al., 2001) }\end{array}$ \\
\hline Ipomoea trifida (Kunth) G. Don & Root knot nematode and root lesion nematode resistance (Sakamoto, 1976) \\
\hline Juglans californica S. Watson & Rootstock (USDA-ARS National Genetic Resources Program, 2012) \\
\hline Juglans hindsii (Jeps.) R. E. Sm. & Rootstock (McGranahan and Leslie, 2009; USDA-ARS National Genetic Resources Program, 2012) \\
\hline Juglans major (Torr.) A. Heller and Juglans & Rootstock for alkaline soil (McGranahan and Leslie, 2009) \\
\hline
\end{tabular}

Anthracnose resistance (McGranahan and Leslie, 2009) and rootstock (USDA-ARS National Genetic Resources Program, 2012)

Downy mildew resistance (Hooftman et al., 2007)

Leaf aphid resistance (Eenink et al., 1982)

Rootstock (USDA-ARS National Genetic Resources Program, 2012)

Winter hardiness (Barnes et al., 1977)

Pest resistance, vigor and yield (Hanna, 1997)

Rootstock (USDA-ARS National Genetic Resources Program, 2012)

Prunus andersonii A. Gray, Prunus pumila L., Prunus pumila L. var. besseyi (L. H. Bailey) Gleason, and Prunus rivularis Scheele

Pyrus calleryana Decne.

Ribes nigrum L.

Ribes uva-crispa L.

Solanum stoloniferum Schltdl. \& Bouché

Tripsacum dactyloides (L.) L.

Rootstock (USDA-ARS National Genetic Resources Program, 2012)

Pest and disease resistance (Barney and Hummer, 2005)

Gall mite resistance (Brennan, 2008)

Late blight resistance (Bradshaw et al., 2006) and potato Y virus resistance (Ross, 1979)

Corn leaf blight resistance (Goodman et al., 1987) and yield improvement and top firing resistance (PrescottAllen and Prescott-Allen, 1986)

Vitis acerifolia Raf., Vitis aestivalis Michx., Vitis cinerea (Engelm.) Engelm. ex Millardet, Vitis cinerea var. helleri (L. H. Bailey) M. O. Moore, Vitis monticola Buckley, Vitis mustangensis Buckley, and Vitis vulpina L.

Vitis labrusca L.

Vitis riparia Michx. and Vitis rupestris Scheele

Rootstock (USDA-ARS National Genetic Resources Program, 2012)

Cold tolerance (Reisch and Pratt, 1996)

Phylloxera vitifoliae resistance (Prescott-Allen and Prescott-Allen, 1986) and rootstock (USDA-ARS National Genetic Resources Program, 2012)

tPublished trait listing adapted from the "Harlan and de Wet Crop Wild Relative Inventory" (Vincent et al., 2012). 
security could benefit significantly from the long-term conservation and exploitation of these taxa. Following the prioritization of such taxa based on their potential use value, planning for conservation will be facilitated through an analysis of the range of distribution of these taxa and the subsequent identification of hotspots of richness of CWRs in the United States as well as geographic and taxonomic gaps in germplasm collections and in situ conservation.

The focus on the gene pools of major agricultural crops during prioritization within the Inventory resulted in a number of minor or locally important crops and WUS, forages, and other nonfood crops holding secondary priority (Supplemental Table S3). Many of these taxa are economically important and their native U.S. genetic resources may have substantial use value. The development and collation of information both on the use of these taxa in breeding programs as well as the value of their associated crops will contribute significantly to their potential for prioritization and subsequent conservation.

Given the considerable development pressures on wild plants in the United States (Stein et al., 2000) and projected increasing impacts from climate change (Loarie et al., 2009), both the urgent collection for ex situ conservation and the management of taxa in conservation areas are warranted. To achieve these goals for the diversity of prioritized taxa, broad partnerships and networks between the federal, state, tribal, and nongovernmental organizations pursuing conservation activities are needed. Because many of the taxa are distributed across national borders and the genetic resources of such species are potentially valuable globally, such efforts should be aligned with neighboring national strategies and with regional and global initiatives to conserve and provide access to CWR diversity.

\section{Supplemental Information Available}

Supplemental material is included with this manuscript. This includes a prioritization of agricultural crops worldwide (Supplemental Table S1), an extended list of threatened U.S. crop wild relatives and wild utilized species (Supplemental Table S2), and a listing of additional prioritized U.S. crop wild relatives and wild utilized species (Supplemental Table S3).

\section{Acknowledgments}

Research by the corresponding author was funded by the Global Crop Diversity Trust, Rome, Italy. We thank the NPGS curators, members of the NPGS Crop Germplasm Committees, and ARS crop experts for their inputs on the Inventory and Gary Kinard, Edward Garvey, Karen Williams, and Larry Stritch for helpful comments on the manuscript.

\section{References}

Abberton, M. 2007. Interspecific hybridization in the genus Trifolium. Plant Breed. 126:337-342. doi:10.1111/j.14390523.2007.01374.x
Amsellem, L., J.L. Noyer, T. Le Bourgeois, and M. HossaertMckey. 2001. Comparison of genetic diversity of the invasive weed Rubus alceifolius Poir. (Rosaceae) in its native range and in areas of introduction, using amplified fragment length polymorphism (AFLP) markers. Mol. Ecol. 9:443-455. doi:10.1046/j.1365-294x.2000.00876.x

Andersson, M.S., and M.C. de Vicente. 2010. Gene flow between crops and their wild relatives. The Johns Hopkins Univ. Press, Baltimore, MD.

Ballington, J.R. 2001. Collection, utilization and preservation of genetic resources of Vaccinium. Hortic. Sci. 36:213-220.

Barnes, D.K., E.T. Bingham, R.P. Murphy, O.J. Hunt, D.F. Beard, W.H. Skrdla, and L.R. Teuber. 1977. Alfalfa germplasm in the United States: Genetic vulnerability, use, improvement and maintenance. ARS Tech. Bull. No. 1571. USDA, Hyattsville, MD. p. 21.

Barney, D., and K. Hummer. 2005. Currants, gooseberries and jostaberries - A guide for growers, marketers and researchers in North America. Haworth Press, Binghampton, NY.

Bilz, M., S.P. Kell, N. Maxted, and R.V. Lansdown. 2011. European red list of vascular plants. Publications Office of the European Union, Luxembourg.

Bossdorf, O., H. Auge, L. Lafuma, W.E. Rogers, E. Siemann, and D. Prati. 2005. Phenotypic and genetic differentiation between native and introduced plant populations. Oecologia 144:1-11. doi:10.1007/s00442-005-0070-z

Boyle, B., N. Hopkins, Z. Lu, J.A. Raygoza Garay, D. Mozzherin, T. Rees, N. Matasci, M.L. Narro, W.H. Piel, S.J. Mckay, S. Lowry, C. Freeland, R.K. Peet, and B.J. Enquist. 2013. The taxonomic name resolution service: An online tool for automated standardization of plant names. BMC Bioinfor. 14:16. doi:10.1186/1471-2105-14-16

Bradshaw, J.E., G.J. Bryan, and G. Ramsay. 2006. Genetic resources (including wild and cultivated Solanum species) and progress in their utilization in potato breeding. Potato Res. 49:49-65. doi:10.1007/s11540-006-9002-5

Brennan, R. 2008. Currants and gooseberries. In: J. Hancock, editor, Temperate fruit crop breeding: Germplasm to genomics. Springer Science and Business Media B.V., New York, NY. p. 177-196.

Bretting, P.K., and G.P. Nabhan. 1986. Ethnobotany of devil's claw (Proboscidea parviflora ssp. parviflora: Martyniaceae) in the greater Southwest. J. Calif. Gt. Basin Anthropol. 8:226-237.

Brummitt, N., and S. Bachman. 2010. Plants under pressure a global assessment. The first report of the IUCN sampled red list index for plants. Natural History Museum, London, UK.

Bureau of Land Management. 2012. Seeds of success. U.S. Department of the Interior, Bureau of Land Management, Washington, DC. http://www.nps.gov/plants/sos/ (accessed 1 Aug. 2012).

Center for Plant Conservation (CPC). 2012. Center for Plant Conservation: Conserving and restoring America's native plants. Center for Plant Conservation, St. Louis, MO. http:// www.centerforplantconservation.org/ (accessed 1 Aug. 2012).

Chuda, A., and A. Adamus. 2009. Aspects of interspecific hybridization within edible Alliaceae. Acta Physiol. Plant. 31:223-227. doi:10.1007/s11738-008-0236-5

Cox, T.S., R.G. Sears, R.K. Bequette, and T.J. Martin. 1995. Germplasm enhancement in winter wheat $\times$ Triticum tauschii backcross populations. Crop Sci. 35:913-919. doi:10.2135/cro psci1995.0011183X003500030047x 
Eenink, A.H., R. Groenwold, and F.L. Dieleman. 1982. Resistance of lettuce (Lactuca) to the leaf aphid Nasonovia ribisnigri: Transfer of resistance from $L$. virosa to $L$. sativa by interspecific crosses and selection of resistant breeding lines. Euphytica 31:291-300. doi:10.1007/BF00021643

El Khlifi, O.K., H. Sharma, and O. Benlhabib. 2004. Transfer of Hessian fly resistance through interspecific crosses between cultivated wheat and four Aegilops species. Plant Genet. Resour. Newsl. 138:43-49.

FAO. 2002. International treaty on plant genetic resources for food and agriculture. FAO, Rome, Ital.

FAO. 2010. Second report on the state of the world's plant genetic resources for food and agriculture. FAO, Rome, Ital.

FAO. 2011. FAOSTAT. FAO, Rome, Italy. http://faostat.fao. org/ (accessed 1 May 2011).

Farooq, S., M. Asghar, N. Iqbal, E. Asian, M. Arif, and T.M. Shah. 1995. Production of salt tolerant wheat germplasm through crossing cultivated wheat with Aegilops cylindrica, I. Field evaluation of salt tolerant germplasm. Cereal Res. Commun. 23:275-282.

Finn, C. 2001. Trailing blackberries: From clear-cuts to your table. Hortic. Sci. 36:236-238.

Flack, J.R. 1970. The spread and domestication of the pecan (Carya illinoensis) in the United States. University of Wisconsin Press, Madison, WI. p. 482.

Flora of North America Association (FNA). 2008a. Flora of North America. Flora of North America Association, Harvard University Herbaria, Cambridge, MA. http:// floranorthamerica.org/ (accessed 1 Jan. 2011).

Flora of North America Association (FNA). 2008b. Flora of North America - Introduction. Flora of North America Association, Harvard University Herbaria, Cambridge, MA. http:// floranorthamerica.org/introduction (accessed 1 Jan. 2011).

Ford-Lloyd, B., M. Schmidt, S.J. Armstrong, O. Barazani, J. Engels, R. Hadas, K. Hammer, S.P. Kell, D. Kang, K. Khoshbakht, Y. Li, C. Long, B. Lu, K. Ma, V.T. Nguyen, L. Qiu, S. Ge, W. Wei, Z. Zhang, and N. Maxted. 2011. Crop wild relatives- undervalued, underutilized and under threat? Bioscience 61:559-565. doi:10.1525/bio.2011.61.7.10

Fowler, C., and T. Hodgkin. 2004. Plant genetic resources for food and agriculture: Assessing global availability. Annu. Rev. Env. Resour. 29:10.1-10.37.

Frese, L., B. Desprez, and D. Ziegler. 2001. Potential of genetic resources and breeding strategies for base-broadening in Beta. In: H.D. Cooper, C. Spillane, and T. Hodgkin, editors, Broadening the genetic base of crop production. CABI, Wallingford, UK. p. 295-309.

Gale, G. 2003. Saving the vine from Phylloxera: A never-ending battle. In: M. Sandler and R. Pinder, editors, Wine: A scientific exploration. Taylor and Francis, London and New York.

Global Biodiversity Information Facility (GBIF). 2012. GBIF Data Portal. GBIF, Copenhagen, Denmark. http://data.gbif.org/ welcome.htm (accessed 1 Jan. 2011).

Global Strategy for Plant Conservation (GSPC). 2002. Convention on biological diversity. Secretariat of the Convention on Biological Diversity, Montreal, QC.

Goodman, R.M., H. Hauptli, A. Crossway, and V.C. Knauf. 1987. Gene transfer in crop improvement. Science 236:48-54. doi:10.1126/science.236.4797.48

Gororo, N.N., H.A. Eagles, R.F. Eastwood, M.E. Nicolas, and R.G. Flood. 2002. Use of Triticum tauschii to improve yield of wheat in low-yielding environments. Euphytica 123:241-254.
doi:10.1023/A:1014910000128

Groombridge, B., and M.D. Jenkins. 2002. World atlas of biodiversity. Prepared by the UNEP World Conservation Monitoring Centre. University of California Press, Berkeley, CA.

Guarino, L., and D.B. Lobell. 2011. A walk on the wild side. Nature Climate Change 1:374-375. doi:10.1038/nclimate1272

Guo, Q., J. Falcone, and J. Brownsmith. 2009. Building the database for introduced plants in the United States. In: K.A. McManus and K.W. Gottschalk, editors, Proceedings of the 20th U.S. Department of Agriculture interagency research forum on invasive species 2009, Annapolis, MD. 13-16 Jan. 2009. Gen. Tech. Rep. NRS-P-51. U.S. Department of Agriculture, Forest Service, Northern Research Station, Newtown Square, PA. p. 73.

Gur, A., and D. Zamir. 2004. Unused natural variation can lift yield barriers in plant breeding. PLoS Biol. 2(10):e245. doi:10.1371/journal.pbio.0020245

Hajjar, R., and T. Hodgkin. 2007. The use of wild relatives in crop improvement: A survey of developments over the last 20 years. Euphytica 156:1-13. doi:10.1007/s10681-007-9363-0

Hanna, W.W. 1997. Influence of cytoplasms from a wild grassy subspecies on dry matter yields in pearl millet. Crop Sci. 37:614616. doi:10.2135/cropsci1997.0011183X003700020050x

Harlan, J.R. 1976. Genetic resources in wild relatives of crops. Crop Sci. 16:329-333. doi:10.2135/cropsci1976.0011183X00 $1600030004 \mathrm{x}$

Harlan,J.R., and J.M.J. de Wet. 1971. Toward a rational classification of cultivated plants. Taxon 20:509-517. doi:10.2307/1218252

Heywood, V.H. 2008. Challenges of in situ conservation of crop wild relatives. Turk. J. Bot. 32:421-432.

Hijmans, R.J., and D. Spooner. 2001. Geographic distribution of wild potato species. Am. J. Bot. 88:2101-2112. doi: $10.2307 / 3558435$

Hoes, J.A., E.D. Putt, and H. Enns. 1973. Resistance to Verticillium wilt in collections of wild Helianthus in North America. Phytopathology 63:1517-1520. doi:10.1094/Phyto-63-1517

Hoffman, D.L., J. Chong, E.W. Jackson, and D.E. Obert. 2006. Characterization and mapping of a crown rust resistance gene complex (Pc58) in TAM O-301. Crop Sci. 46:2630-2635. doi:10.2135/cropsci2006.01.0014

Hooftman, D.A.P., M.J. De Jong, G.B. Oostermeijer, and H.J.C.M. den Nijs. 2007. TI: Modelling the long-term consequences of crop $\times$ wild relative hybridization: A case study using four generations of hybrids. J. Appl. Ecol. 44(5):1035-1045. doi:10.1111/j.1365-2664.2007.01341.x

Hulke, B.S., J.F. Miller, T.J. Gulya, and B.A. Vick. 2010. Registration of the oilseed sunflower genetic stocks HA 458, HA 459, and HA 460 possessing genes for resistance to downy mildew. J. Plant Reg. 4:1-5. doi:10.3198/jpr2009.06.0356crc

Hummer, K.E., N. Bassil, and W. Njuguna. 2011. Fragaria. In: C. Kole, editor, Wild crop relatives: Genomic and breeding resources. Springer, Berlin, Germany.

Iltis, H.H. 1988. Serendipity in the exploration of biodiversity. What good are weedy tomatoes? In: E.O. Wilson, editor, Biodiversity. National Academy Press, Washington, DC. p. 98-105.

International Union for Conservation of Nature, Species Survival Commission. 2008. Crop wild relative specialist group. Bioversity International, Rome, Italy. http://www.cwrsg. org/index.asp (accessed 1 Jan. 2012).

International Union for Conservation of Nature (IUCN). 2012. The IUCN red list of threatened species. Version 2012.1. International Union for Conservation of Nature and Natural 
Resources, Cambridge, UK. http://www.iucnredlist.org/ (accessed 1 Oct. 2012).

Jan, C.C. 1992. Registration of sunflower amphiploid germplasm line, ANN-BOL-AMP1. Crop Sci. 32:1513. doi:10.2135/cro psci1992.0011183X003200060051x

Jan, C.C., and J.M. Chandler. 1988. Registration of powdery mildew resistant sunflower germplasm pool, PM 1. Crop Sci. 28:1040. doi:10.2135/cropsci1988.0011183X002800060072x

Jan, C.C., J.M. Fernandez-Martinez, J. Ruso, and J. MuñozRuz. 2002. Registration of four sunflower germplasms with resistance to Orobanche cumana race F. Crop Sci. 42:2217-2218. doi:10.2135/cropsci2002.2217

Jan, C.C., J.F. Miller, G.J. Seiler, and G.N. Fick. 2006. Registration of one cytoplasmic male sterile and two fertility restoration sunflower genetic stocks. Crop Sci. 46:1835. doi:10.2135/ cropsci2005.12-0507

Jan, C.C., Z. Quresh, and T.J. Gulya. 2004. Registration of seven rust resistant sunflower germplasms. Crop Sci. 44:1887-1888. doi:10.2135/cropsci2004.1887

Jarvis, A., A. Lane, and R.J. Hijmans. 2008. The effect of climate change on crop wild relatives. Agric. Ecosyst. Environ. 126:13-23. doi:10.1016/j.agee.2008.01.013

Jarvis, A., K. Williams, D.E. Williams, L. Guarino, P.J. Caballero, and G. Mottram. 2005. Use of GIS for optimizing a collecting mission for a rare wild pepper (Capsicum flexuosum Sendtn.) in Paraguay. Genet. Resour. Crop Evol. 52:671-682. doi:10.1007/s10722-003-6020-x

Kell, S.P., H. Knüpffer, S.L. Jury, B.V. Ford-Lloyd, and N. Maxted. 2008. Crops and wild relatives of the Euro-Mediterranean region: Making and using a conservation catalogue. In: N. Maxted, B.V. Ford-Lloyd, S.P. Kell, J.M. Iriondo, M.E. Dulloo, and J. Turok, editors, Crop wild relative conservation and use. CAB Int., Wallingford, UK. p. 69-109.

Khrustaleva, L., and C. Kik. 1998. Cytogenetical studies in the bridge cross Allium cepa $\times($ A. fistulosum $\times$ A. roylei $)$. Theor. Appl. Genet. 96:8-14. doi:10.1007/s001220050702

Kraft, K.H., J.J. Luna-Ruíz, and P. Gepts. 2012. A new collection of wild populations of Capsicum in Mexico and the southern United States. Genet. Resour. Crop Evol. 60:225-232. doi:10.1007/s10722-012-9827-5

Lexer, C., Z. Lai, and L.H. Rieseberg. 2004. Candidate gene polymorphisms associated with salt tolerance in wild sunflower hybrids: Implications for the origin of Helianthus paradoxus, a diploid hybrid species. New Phytol. 161:225-233. doi:10.1046/j.1469-8137.2003.00925.x

Loarie, S.R., P.B. Duffy, H. Hamilton, G.P. Asner, C.B. Field, and D.D. Ackerly. 2009. The velocity of climate change. Nature 462(7276):1052-1055. doi:10.1038/nature08649

Ma, H., R.P. Singh, and A. Mujeeb-Kazi. 1995. Resistance to stripe rust in O. rufipogon, T. tauschii and their synthetic hexaploids. Euphytica 82:117-124. doi:10.1007/BF00027057

Magos Brehm, J., N. Maxted, B.V. Ford-Lloyd, and M.A. Martins-Loução. 2007. National inventories of crop wild relatives and wild harvested plants: Case-study for Portugal. Genet. Resour. Crop Evol. 55:779-796. doi:10.1007/s10722007-9283-9

Mallikarjuna, N., J. Deepak, and R. Prabhakar. 2006. Introgression of Cajanus platycarpus genome into cultivated pigeonpea, $C$. cajan. Euphytica 149:161-167. doi:10.1007/s10681-005-9063-6

Maxted, N., Z.I. Akparov, M. Aronsson, Å. Asdal, and A. Avagyan, A. Bartha, et al. 2012b. Current and future threats and opportunities facing European crop wild relative and landrace diversity. In N. Maxted, N., M.E. Dulloo, B.V. Ford-Lloyd, L. Frese, J.M. Iriondo, J.M. Pinheiro de Carvalho, et al., editors, Agrobiodiversity conservation: Securing the diversity of crop wild relatives and landraces. CAB Int., Wallingford, UK. p. 333-354.

Maxted, N., E. Dulloo, B.V. Ford-Lloyd, J.M. Iriondo, and A. Jarvis. 2008. Gap analysis: A tool for complementary genetic conservation assessment. Diversity Distrib. 14:1018-1030. doi:10.1111/j.1472-4642.2008.00512.x

Maxted, N., B.V. Ford-Lloyd, and J.G. Hawkes. 1997. Complementary conservation strategies. In: N. Maxted, B.V. Ford-Lloyd, and J.G. Hawkes, editors, Plant genetic conservation: The in situ approach. Chapman and Hall, London, UK. p. 20-55.

Maxted, N., B.V. Ford-Lloyd, S.L. Jury, S.P. Kell, and M.A. Scholten. 2006. Towards a definition of a crop wild relative. Biodivers. Conserv. 15:2673-2685. doi:10.1007/s10531-005-5409-6

Maxted, N., and S.P. Kell. 2009. Establishment of a global network for the in situ conservation of crop wild relatives: Status and needs. FAO Commission on Genetic Resources for Food and Agriculture, Rome, Italy. p. 266.

Maxted, N., S.P. Kell, B.V. Ford-Lloyd, E. Dulloo, and Á. Toledo. 2012a. Toward the systematic conservation of global crop wild relative diversity. Crop Sci. 52:774-785. doi:10.2135/ cropsci2011.08.0415

McCouch, S., M. Sweeney, J. Li, H. Jiang, M. Thomson, E. Septiningsih, J. Edwards, P. Moncada, J. Xiao, A. Garris, T. Tai, C. Martinez, J. Tohme, M. Sugiono, A. McClung, L. Yuan, and S. Ahn. 2007. Through the genetic bottleneck: O. rufipogon as a source of trait enhancing alleles for $O$. sativa. Euphytica 154:317-339. doi:10.1007/s10681-006-9210-8

McGranahan, G., and C. Leslie. 2009. Breeding walnuts (Juglans regia). In: S.M. Jain and P.M. Priyadarshan, editors, Breeding plantation tree crops: Temperate species. Springer, New York, NY. p. 249-273.

McGuffin, M., and American Herbal Products Association. 2000. Herbs of commerce. 2nd ed. American Herbal Products Association, Silver Spring, MD.

Meilleur, B.A., and T. Hodgkin. 2004. In situ conservation of crop wild relatives: Status and trends. Biodivers. Conserv. 13:663684. doi:10.1023/B:BIOC.0000011719.03230.17

Mii, M. 2009. Breeding ornamental plants through interspecific hybridization using advanced techniques with a special focus on Dianthus, Primula, Cosmos, and Kalanchoe. Acta Hortic. 836:63-72.

Miller, J.F., and T.J. Gulya. 1988. Registration of six downy mildew resistant sunflower germplasm lines. Crop Sci. 28:1040-1041. doi:10.2135/cropsci1988.0011183X002800060073x

Miller, J.F., and T.J. Gulya. 1999. Registration of eight Sclerotiniatolerant sunflower germplasm lines. Crop Sci. 39:301-302. doi:10.2135/cropsci1999.0011183X003900010075x

Nabhan, G.P. 1985. Native crop diversity in Aridoamerica: Conservation of regional gene pools. Econ. Bot. 39:387-399. doi:10.1007/BF02858746

Nabhan, G.P. 1990. Conservationist and forest service join forces to save wild chiles. Diversity Magazine 6:47-48.

Native Seed Network. 2010. Native seed network database. Native Seed Network, Corvallis, OR. http://www. nativeseednetwork.org (accessed 1 Jan. 2011).

NatureServe. 2009. NatureServe explorer: An online encyclopedia of life. Version 7.1. NatureServe, Arlington, VA. http://www. natureserve.org/explorer/ (accessed 1 Apr. 2010). 
Ortiz, R., K.D. Sayre, B. Govaerts, R. Gupta, G.V. Subbarao, T. Ban, D. Hodson, J.M. Dixon, J.I. Ortiz-Monasterio, and M. Reynolds. 2008. Climate change: Can wheat beat the heat? Agric. Ecosyst. Environ. 126:46-58. doi:10.1016/j. agee.2008.01.019

Parra-Quijano, M., J.M. Iriondo, and E. Torres. 2011. Improving representativeness of genebank collections through species distribution models, gap analysis and ecogeographical maps. Biodivers. Conserv. 21:79-96. doi:10.1007/s10531-011-0167-0

Pavek, D.S., W.F. Lamboy, and E.J. Garvey. 2001. In situ conservation of America's wild grapes. Hortic. Sci. 36:232-235.

Peel, M.D., K.H. Asay, B.L. Waldron, K.B. Jensen, J.G. Robins, and I.W. Mott. 2009. 'Don', a diploid falcata alfalfa for western U.S. rangelands. J. Plant Reg. 3:115-118. doi:10.3198/ jpr2008.10.0597crc

Pena, R.J., J. Zarco-Hernandez, and A. Mujeeb-Kazi. 1995. Glutenin subunit compositions and breadmaking quality characteristics of synthetic hexaploid wheats derived from $O$. rufipogon $\times$ Triticum tauschii (Coss.) Schmal crosses. J. Cereal Sci. 21:15-23. doi:10.1016/S0733-5210(95)80004-2

Peredo, E.L., M. Ángeles Revilla, B.M. Reed, B. Javornik, E. Cires, J.A. Fernández Prieto, and R. Arroyo-García. 2010. The influence of European and American wild germplasm in hop (Humulus lupulus L.) cultivars. Genet. Resour. Crop Evol. 57:575-586. doi:10.1007/s10722-009-9495-2

Pestsova, E.G., A. Borner, and M.S. Roder. 2006. Development and QTL assessment of Triticum aestivum-Aegilops tauschii introgression lines. Theor. Appl. Genet. 112:634-647. doi:10.1007/s00122-005-0166-1

Phillips, O.L., and B.A. Meilleur. 1998. Usefulness and economic potential of the rare plants of the United States: A statistical survey. Econ. Bot. 52(1):57-67. doi:10.1007/BF02861295

Pickering, R., and P.A. Johnston. 2005. Recent progress in barley improvement using wild species of Hordeum. Cytogenet. Genome Res. 109:344-349. doi:10.1159/000082418

Plant Germplasm Operations Committee. 1999. In situ subcommittee. The American wild relatives of crops: In situ conservation guidelines. USDA National Plant Germplasm System Report. USDA, Beltsville, MD.

Plant Germplasm Operations Committee. 2010. Minutes of the annual meeting, Geneva, NY. 28-29 July 2010. USDA National Germplasm Resources Laboratory, Beltsville, MD.

Prescott-Allen, R., and C. Prescott Allen. 1986. The first resource: Wild species in the North American economy. Yale University, New Haven, CT.

Prescott-Allen, R., and C. Prescott-Allen. 1990. How many plants feed the world? Conserv. Biol. 4:365-374. doi:10.1111/j.1523-1739.1990.tb00310.x

Putt, E.D. 1978. History and present world status. In: J.P. Carter, editor, Sunflower and science and technology. ASA, Madison, WI. p. 1-29.

Ramírez-Villegas, J., C. Khoury, A. Jarvis, D.G. Debouck, and L. Guarino. 2010. A gap analysis methodology for collecting crop genepools: A case study with Phaseolus beans. PLoS ONE 5(10):e1349. doi:10.1371/journal.pone.0013497

Rawal, K.M. 1975. Natural hybridization among wild, weedy and cultivated Vigna unguiculata (L.) Walp. Euphytica 24:699-707. doi:10.1007/BF00132908

Reisch, B., and C. Pratt. 1996. Grapes. In: J. Janick and J. Moore, editors, Fruit breeding volume II: Vine and small fruit crops. John Wiley \& Sons, New York, NY. p. 297-369.

Rogers, C.E., T.E. Thompson, and G.J. Seiler. 1984. Registration of three Helianthus germplasms for resistance to the sunflower moth. Crop Sci. 24:212-213. doi:10.2135/cropsci1984.001118 3X002400010058x

Ross, H. 1979. Wild species and primitive cultivars as ancestors of potato varieties. In: A.C. Zeven and A.M. van Harten, editors, Proceedings of the conference broadening the genetic base of crops, Wageningen, Netherlands. 3-7 July 1978. Centre for Agricultural Publishing and Documentation, Wageningen, Netherlands. p. 237-245.

Ruge-Wehling, B., A. Linz, A. Habeku, and P. Wehling. 2006. Mapping of RYMl6Hb, the second soilborne virus resistance gene introgressed from Hordeum bulbosum. Theor. Appl. Genet. 113:867-873. doi:10.1007/s00122-006-0345-8

Rygulla, W., R. Snowdon, C. Eynck, B. Koopmann, A. Von Tiedemann, W. Lühs, and W. Friedt. 2007. Broadening the genetic basis of Verticillium longisporum resistance in Brassica napus by interspecific hybridization. Phytopathology 97:13911396. doi:10.1094/PHYTO-97-11-1391

Sakamoto, S. 1976. Breeding of a new sweet potato variety, Minamiyutaka, by the use of wild relatives. Jpn. Agric. Res. Q. 10(4):183-186.

Seiler, G.J. 1991a. Registration of 15 interspecific sunflower germplasm lines derived from wild annual species. Crop Sci. 31:1389-1390. doi:10.2135/cropsci1991.0011183X003100050 $081 \mathrm{x}$

Seiler, G.J. 1991b. Registration of 13 downy mildew tolerant interspecific sunflower germplasm lines derived from wild annual species. Crop Sci. 31:1714-1716.

Seiler, G.J. 1991c. Registration of six interspecific sunflower germplasm lines derived from wild perennial species. Crop Sci. 31:1097-1098. doi:10.2135/cropsci1991.0011183X003100040074x

Seiler, G.J. 2000. Registration of 10 interspecific germplasms derived from wild perennial sunflower. Crop Sci. 40:587-588.

Seiler, G.J., and T.J. Gulya Jr. 2004. Exploration for wild Helianthus species in North America: Challenges and opportunities in the search for global treasures. In: International Sunflower Conference Proceedings, v.1, Fargo, ND. 29 Aug.-2 Sept. 2004. International Sunflower Association, Paris, France. p. 43-68.

Smith, B.D. 2006. Eastern North America as an independent center of plant domestication. Proc. Natl. Acad. Sci. 103:1222312228. doi:10.1073/pnas.0604335103

Stein, B.A., L.S. Kutner, and J.S. Adams, editors. 2000. Precious heritage: The status of biodiversity in the United States. Oxford Univ. Press, New York, NY.

Suszkiw, J. 2005. Hessian fly resistant wheat germplasm available. USDA-ARS, Washington, DC. http://www.ars.usda.gov/is/ pr/2005/050211.htm (accessed 1 Aug. 2012).

Takeda, K., and K.J. Frey. 1976. Contributions of vegetative growth rate and harvest index to grain yield of progenies from Avena sativa $\times$ A. sterilis Crosses. Crop Sci. 16:817-821. doi:10.2135/cropsci1976.0011183X001600060020x

Tanksley, S.D., and S.R. McCouch. 1997. Seed banks and molecular maps: Unlocking genetic potential from the wild. Science 277:1063-1066. doi:10.1126/science.277.5329.1063

Thompson, M., H. Lagerstedt, and S. Mehlenbacher. 1996. Hazelnuts. In: J. Janick and J. Moore, editors, Fruit breeding, volume III: Nuts. John Wiley \& Sons Inc., New York, NY. p. 125-184.

Toubia-Rahme, H., P.A. Johnston, R.A. Pickering, and B.J. Steffenson. 2003. Inheritance and chromosomal location of Septoria passerinii resistance introgressed from Hordeum bulbosum into Hordeum vulgare. Plant Breed. 122:405-409. 
doi:10.1046/j.1439-0523.2003.00850.x

Ureta, C., E. Martinez-Meyer, H.R. Perales, and E.R. AlvarezBuylla. 2011. Projecting the effects of climate change on the distribution of maize races and their wild relatives in Mexico. Glob. Change Biol. 18:1073-1082. doi:10.1111/j.13652486.2011.02607.x

USDA-ARS National Genetic Resources Program. 2011. World economic plants: A standard reference. National Germplasm Resources Laboratory, Beltsville, MD. http://www.ars-grin. gov/cgi-bin/npgs/html/wep.pl (accessed 1 Jan. 2011).

USDA-ARS National Genetic Resources Program. 2012. GRIN (Germplasm Resources Information Network) taxonomy for plants. National Germplasm Resources Laboratory, Beltsville, MD. http://www.ars-grin.gov/ sbmljw/cgi-bin/index. pl?language $=$ en (accessed 1 Jan. 2012).

USDA-Natural Resources Conservation Service (USDA-NRCS). 2010. The PLANTS Database. National Plant Data Center, Baton Rouge, LA. http://plants.usda.gov (accessed 23 Apr. 2010).

U.S. Forest Service (USFS). 2010. Celebrating wildflowers ethnobotany - wild crop progenitors. USFS, Washington, DC. http://www.fs.fed.us/wildflowers/ethnobotany/ progenitors.shtml (accessed 1 Aug. 2012).

Vavilov, N.I. 1926. Studies on the origin of cultivated plants. Bulletin of Applied Botany. Genet. Plant Breed. 16:1-248.

Villareal, R.L., A. Mujeeb-Kazi, G. Fuentes-Davila, and S. Rajaram. 1996. Registration of four synthetic hexaploid wheat germplasm lines derived from O. rufipogon $\times$ T. tauschii crosses and resistance to kernal bunt. Crop Sci. 36:218. doi:10.2135/ cropsci1996.0011183X003600010056x

Villareal, R.L., K. Sayre, O. Banuelos, and A. Mujeeb-Kazi. 2001. Registration of four synthetic hexaploid wheat (O. rufipogon/ Aegilops tauschii) germplasm lines tolerant to waterlogging. Crop Sci. 41:274. doi:10.2135/cropsci2001.411274x

Vincent, H.A., J.H. Wiersema, S.L. Dobbie, S.P. Kell, H. Fielder, N.P. Castañeda Alvarez, L. Guarino, R. Eastwood, B. León, and N. Maxted. 2012. A prioritised crop wild relative inventory to help underpin global food security. The Harlan and de Wet Crop Wild Relative Inventory. The Global Crop Diversity Trust, Bonn, Germany. http://www.cwrdiversity. org/checklist/ (accessed 1 Jan. 2012).

Volk, G.M., and C.M. Richards. 2011. Integration of georeferencing, habitat, sampling, and genetic data for documentation of wild plant genetic resources. Hortic. Sci. 46(11):1446-1449.
Wang, W., B. Vinocur, and A. Altaian. 2003. Plant responses to drought, salinity and extreme temperatures: Towards genetic engineering for stress tolerance. Planta 218:1-14. doi:10.1007/ s00425-003-1105-5

Whelan, E.D.P., and W. Dedio. 1980. Registration of sunflower germplasm composite crosses CMG-1, CMG-2, and CMG-3. Crop Sci. 20:832. doi:10.2135/cropsci1980.0011183X002000 060066x

Wiersema, J.H., and B. León. 1999. World economic plants: A standard reference. CRC Press LLC, Boca Raton, FL.

Wiersema, J.H., B. León, and E.J. Garvey. 2012. Identifying wild relatives of subtropical and temperate fruit and nut crops. Acta Hortic. 948:285-288.

Wilkes, G. 2007. Urgent notice to all maize researchers: Disappearance and extinction of the last wild teosinte population is more than half completed. A modest proposal for teosinte evolution and conservation in situ: The Balsas, Guerrero, Mexico. Maydica 52:49-58.

Xiao, J., S. Grandillo, S.N. Ahn, S.R. McCouch, and S.D. Tanksley. 1996. Genes from wild rice improve yield. Nature 384:223-224. doi:10.1038/384223a0

Xiu-Jin, L., L. Deng-Cai, and W. Zhi-Rong. 1997. Inheritance in synthetic hexaploid wheat 'RSP' of sprouting tolerance derived from Aegilops tauschii Coss. Euphytica 95:321-323. doi:10.1023/A:1003078801358

Zamir, D. 2001. Improving plant breeding with exotic genetic libraries. Nat. Genet. 2:983-989. doi:10.1038/ni1101-983

Zhang, L., R.A. Pickering, and B.G. Murray. 2001. Hordeum vulgare $\times H$. bulbosum tetraploid hybrid provides useful agronomic introgression lines for breeders. N. Z. J. Crop Hortic. 29:239246. doi:10.1080/01140671.2001.9514185

Zizumbo-Villarreal, D., and P. Colunga-GarcíaMarín. 2010. Origin of agriculture and plant domestication in west Mesoamerica. Genet. Resour. Crop Evol. 57:813-825. doi:10.1007/s10722-009-9521-4

Zizumbo-Villarreal, D., P. Colunga-GarciaMarin, E. Payro de la Cruz, P. Delgado-Valerio, and P. Gepts. 2005. Population structure and evolutionary dynamics of wildweedy-domesticated complexes of common bean in a Mesoamerican region. Crop Sci. 45:1073-1083. doi:10.2135/ cropsci2004.0340 